\title{
THE INFLUENCE OF THREE STAGE FISHBOWL DECISION LEARNING METHOD ON MATHEMATICAL LEARNING ABILITY
}

\author{
By : \\ Tua Halomoan Harahap, M.Pd ${ }^{(1)}$ Asrar Aspia Manurung.,M.Pd ${ }^{(2)}$, \\ tuaholomoan@umsu.ac.id
}

\begin{abstract}
This study aims to determine the effect of the application of the Three Stage Fishbowl Decision learning method to the ability to learn mathematics in students of SMK Muhammadiyah 9 Medan and how significant the Three Stage Fishbowl Decision learning method affects the mathematics learning ability of students of SMK Muhammadiyah 9 MedanT.P 2016/2017. The research instrument used was a test in the form of awa 1 test (pretest) and final test (post-test) consisting of 5 items each of the initial test (pretest) and 5 items of the final test (post-test). The validity test results of 15 item items obtained were 11 valid item items and 4 invalid item items. As the population of this study all students of class XI of SMK Muhammadiyah 9 Medan totaled 93 students, so the sample in this study was class XI TKR which numbered 68 students. The reliability test results of 15 valid obtained that 11 questions were reliable. After raining data the mathematical understanding ability was found to be tcount $>$ ttable, thitung (5.34)> ttable (1.99656). Then $\mathrm{H} \alpha$ is accepted and $\mathrm{H} 0$ is rejected. So it can be concluded from the hypothesis test that students' mathematics learning ability in the experimental class is better than the control class. This means that there is an influence between the Three Stage Fishbowl Decision learning method on the ability to learn mathematics in students of SMK Muhammadiyah 9 Medan T.P 2016/2017. The magnitude of the influence of Three Stage Fishbowl Decision learning methods on the ability to learn mathematics cubes and blocks in class XI students of SMK Muhammadiyah 9 Medan T.P $2016 / 2017$ is $2.89 \%$.
\end{abstract}

Keywords: The Effect of Using Three Stage Fishbowl Decision Learning Methods Against Mathematics Learning Ability

\section{PRELIMINARY}

Mathematics lessons are there and studied, starting from Elementary School to Higher Education level, both globally and specifically. Even at the preschool level, mathematics has begun to be introduced, but mathematics has become a frightening specter and is a difficult subject for students in general.

Low student learning ability is caused by many factors. One of them is the factor of students where their activity is low (accustomed to being quiet in the learning process) and their initial ability is also low in terms of the students' national exam scores when they first enter school. The teacher factor also influences because it is normal to use teacher-centered learning so that students only listen.

In essence, learning is the process of finding, finding and seeing the main problem. Learning is also said as an effort to solve the problem or problem at hand. This is directly related to the ability that must be possessed in the standard mathematics learning process (mathematical processes) as stated by Bahrul and Yusuf (2011: 214) that mathematics is one of learning involving several 
abilities in the standard process, this includes the ability to reason, analyze, communicate ideas, formulating and problem solving abilities.

From the description above, the ability to learn mathematics is very important for students and their future. Learning experts agree that the ability to learn mathematics within certain limits, can be formed through the fields of study and disciplines taught.

In addition, learning ability is a general goal of high school learning, this is stated in the Ministry of National Education (2006: 1) KTSP mathematics content standards (2006: 1) include:

(1) Understanding mathematical concepts, explaining the interrelationships between concepts and applying the concept of an algorithm, flexibly, accurately, efficiently and precisely in problem solving, (2) Using reasoning on patterns and traits, doing mathematical manipulation in making generalizations, compiling evidence, or explaining mathematical ideas and statements, (3) Solve problems that include the ability to understand problems, design mathematical models, solve models and interpret the solutions obtained, (4) communicate ideas with symbols, tables, diagrams, or other media to clarify the state of the problem. Having an attitude of appreciating the usefulness of mathematics in life, namely having curiosity, attention and interest in learning mathematics, as well as being tenacious and confident in solving problems.

In the current curriculum in Indonesia, which is the educational unit level curriculum (KTSP), every student who has obtained mathematics learning at school is expected to have the abilities listed in the mathematics learning goals outlined above. In this case the ability to learn mathematics is very important

by students, because mathematics can help in solving problems both in other learning and in everyday life.

The current condition is that the level of mathematical ability of students has not been developed optimally or is classified as low. Efforts to get the most out of the learning process, of course creative and innovative thinking is needed. Innovation in the learning process is needed especially in order to improve students' mathematical problem solving abilities towards the maximum. This innovation can be done by using several models, strategies, methods, approaches, and learning techniques.

Many learning models and techniques have been developed to overcome all problems in the learning process. But what happens in practice is still not appropriate to use.

One type of learning recommended is the three stage fishbowl decision learning method which is a learning activity between four or more people carried out collaboratively in a group to solve a problem in order to achieve certain goals and further suppress the meaningfulness of learning. Three-stage fishbowl decision learning methods are very effective for building students' mathematical learning solutions and abilities. By participating in the three stage fishbowl decision learning method, it will be relatively trained to solve the types of problems and evaluate the process of solving them.

Based on the description of the problems stated above, the writer is interested in choosing the title: "The Effect of Using Three Stage Fishbowl Decision Learning Methods Against Mathematics Learning Ability in Students of SMK Muhammadiyah 9 Medan T.P 2016/2017".

\section{RESEARCH METHODS}


The study population is the entire subject studied in the form of humans, objects, events and symptoms that occur. Population is very important because it is the object needed to solve the problem so that research objectives can be achieved.

According to Suharsimi Arikunto said that the population is the whole subject of research. In this study the population was all students of class XI consisting of 3 classes with a total of 93 students of SMK Muhammadiyah 9 Medan 2016/2017 Academic Year.

\section{RESEARCH RESULTS AND DISCUSSION}

\section{Research result}

In this study consists of two variables, namely the independent variable $(\mathrm{X})$ and the dependent variable (Y).

a. The Independent Variable (X) is a Three Stage Fishbowl Decision Learning Method.

b. The Bound Variable (Y) is the Students' Mathematics Learning Ability.

c. Initial Test Score (Pretest)

Pretest data is used to determine whether the initial abilities of students in the experimental class and the control class are different or the same. Pretest data from each class consisted of 34 experimental class students and 34 control class students. From the results of data processing and pretest for each class, namely the experimental class and the control class, the maximum value, minimum value, average value, and standard deviation are obtained as follows:

Table 4.1

Descriptive Statistics of Pretest Data for the Experiment Class and the Control Class

\begin{tabular}{|l|l|l|l|l|l|l|}
\hline Class & $\mathrm{N}$ & $\begin{array}{l}\text { Minimum } \\
\text { Value }\end{array}$ & $\begin{array}{l}\text { Maximum } \\
\text { Value }\end{array}$ & Mean & Variance & $\begin{array}{l}\text { Std. } \\
\text { deviation }\end{array}$ \\
\hline Experiment & 34 & 50 & 75 & 62,38 & 73,11 & 8,55 \\
\hline Control & 34 & 50 & 78 & 61,91 & 88,60 & 9,41 \\
\hline
\end{tabular}

Based on the data in the table above, it appears that the average pretest score of the experimental class is 62.38 with a minimum score of 50 and a maximum score of 75 and a variance of 73.11 with a standard deviation of 8.55. While the average score of the control class pretest was 61.91 with a minimum score of 50 and a maximum score of 78 and a variance of 88.60 with a standard deviation of 9.41. This shows that the pretest value in the control class is higher than the pretest value of the experimental class, so it can be seen that the learning outcomes of students in the control class are better than the experimental class before being treated with the Three stage fishbowl decision method.

d. Final Test Value (post-test)

After being given the Three stage fishbowl decision method in the experimental class and the conventional learning model in the control class, the researcher gives a final test (post-test) of each class, this test aims to see an increase in students' mathematical learning ability achieved by each experiment and control class.

Table 4.2

Descriptive Statistics of Pretest Data for the Experiment Class and the Control Class

\begin{tabular}{|l|l|l|l|l|l|l|}
\hline Class & $\mathrm{N}$ & $\begin{array}{l}\text { Maximum } \\
\text { Value }\end{array}$ & $\begin{array}{l}\text { Minimum } \\
\text { Value }\end{array}$ & Mean & Variance & $\begin{array}{l}\text { Std. } \\
\text { deviation }\end{array}$ \\
\hline Experiment & 34 & 100 & 80 & 90,23 & 42,06 & 6,48 \\
\hline
\end{tabular}




\begin{tabular}{|l|l|l|l|l|l|l|}
\hline Control & 34 & 93 & 70 & 80,35 & 58,23 & 7,63 \\
\hline
\end{tabular}

Based on the data in the table above, it appears that the average post-test experimental class is 90.23 with a minimum value of 80 and a maximum value of 100 , with a variance of 42.06 and a standard deviation of 6.48. While the average control class is 80.35 with a minimum value of 70 and a maximum value of 93 , with a variance of 58.23 and a standard deviation of 7.63. This shows that the post-test value of the experimental class is higher than the control class, so it can be said that the learning ability of the experimental class is higher than the control class.

Based on the above conclusions through the average value contained in the experimental class and the control class, it can be concluded that the learning of the Three stage Fishbowl Decision model is effective in improving the learning ability of students in class XI TKR SMK Muhammadiyah 9 Medan in mathematics subject matter in Cubes and Beams.

2. What percentage of the effect of the use of the Three stage Fishbowl Decision learning method is effective in increasing the learning ability of students of Cubes and Beams material.

To find out what percentage of the effect of the use of the Three stage fishbowl Decision method is effective in improving the learning ability of students of Cubes and Beams material. Before testing the hypothesis, the analysis requirements test is normality and linearity test.

1. Data Normality Test

a) Test the normality of post-test data for the Experiment class

Table 4.4

Test Normality Post-test Experiment Class

\begin{tabular}{|l|l|l|l|l|l|l|l|l|}
\hline $\mathrm{Xi}$ & $\mathrm{Fi}$ & $\mathrm{Zn}$ & $\mathrm{Zi}$ & $\mathrm{Lt}$ & $\mathrm{F}(\mathrm{Zi})$ & $\mathrm{S}(\mathrm{Zi})$ & $\mid \mathrm{F}(\mathrm{Zi})-\mathrm{S}(\mathrm{Zi})$ & $\mathrm{F}(\mathrm{Zi})-\mathrm{S}(\mathrm{Zi})$ \\
\hline 80 & 3 & 3 & -1.5795 & 0.151 & 0.05711 & 0.08824 & -0.03112696 & 0.031126958 \\
\hline 82 & 4 & 7 & -1.2709 & 0.151 & 0.10189 & 0.20588 & -0.10399645 & 0.103996454 \\
\hline 85 & 4 & 11 & -0.8079 & 0.151 & 0.20957 & 0.32353 & -0.11395987 & $\mathbf{0 . 1 1 3 9 5 9 8 7 2}$ \\
\hline 88 & 3 & 14 & -0.345 & 0.151 & 0.36506 & 0.41176 & -0.04669978 & 0.046600777 \\
\hline 90 & 5 & 19 & -0.0363 & 0.151 & 0.48552 & 0.55882 & -0.07330627 & 0.073306268 \\
\hline 92 & 2 & 21 & 0.27233 & 0.151 & 0.60732 & 0.61765 & -0.01033076 & 0.01033076 \\
\hline 95 & 6 & 27 & 0.73529 & 0.151 & 0.76892 & 0.79412 & -0.02519784 & 0.025197842 \\
\hline 96 & 1 & 28 & 0.88962 & 0.151 & 0.81316 & 0.82353 & -0.01036571 & 0.010365708 \\
\hline 98 & 2 & 30 & 1.19826 & 0.151 & 0.88459 & 0.88235 & 0.00223858 & 0.002238584 \\
\hline 100 & 4 & 34 & 1.5069 & 0.151 & 0.93408 & 1 & -0.06591827 & 0.065918267 \\
\hline
\end{tabular}

Based on the above table, the price of Lhitung $=0.113959872$ is obtained, while from the list of liliefors at a significant level $\alpha=0.05$ and $\mathrm{n}=34$ are:

$\frac{0,886}{\sqrt{n}}=\frac{0,886}{\sqrt{34}}=\frac{0,886}{5,830}=0,151$

Thus, the price of Lhitung $(0.113959872)<$ Ltable $(0.151)$ is obtained, which means the value of learning group data using the Three Stage Fishbowl Decision method comes from populations that are normally distributed. The normality test of group data of the Three Stage Fishbowl Decision method above is as follows: 
Known :

$\bar{x}=90.2353, S=6.48, n=34$

Determine standard numbers with the formula:

$z_{i}=\frac{x_{1}-\bar{x}}{s}=\frac{80-90.2353}{6,48}=-1,5795$

To determine $\mathrm{F}(\mathrm{Zi})$, the area value below the standard normal curve is used. How to determine $\mathrm{F}$ ( $\mathrm{Zi})$ is $\mathrm{Z}(0.05)$ use the $\mathrm{Z}$ table.

Determine the value of $\mathrm{S}(\mathrm{Zi})$ with the formula:

$$
\mathrm{S}\left(\mathrm{Z}_{1}\right)=\frac{\text { f komulatif }}{n}=\frac{3}{34}=0,08824
$$

This is to find the next $\mathrm{S}(\mathrm{Zi})$ data.

Determine Lhitung with the formula:

$\mathrm{L}=\left|\mathrm{F}\left(\mathrm{Z} \_\mathrm{i}\right)-\mathrm{S}\left(\mathrm{z} \_\mathrm{i}\right)\right|$

$\mathrm{L}=|0.05711-0.08824|$

$\mathrm{L}=|-0,03112696|$

$\mathrm{L}=0.03112696$

Similarly, to find the next Lhitung.

b). Test normality for Post-test Control class data

Table 4.6

Control Class Post-test Normality Test

\begin{tabular}{|l|l|l|l|l|l|l|l|l|}
\hline $\mathrm{Xi}$ & $\mathrm{Fi}$ & $\mathrm{Zn}$ & $\mathrm{Zi}$ & $\mathrm{Lt}$ & $\mathrm{F}(\mathrm{Zi})$ & $\mathrm{S}(\mathrm{Zi})$ & $\mid \mathrm{F}(\mathrm{Zi})-\mathrm{S}(\mathrm{Zi})$ & $\mathrm{F}(\mathrm{Zi})-\mathrm{S}(\mathrm{Zi})$ \\
\hline 70 & 4 & 4 & -1.3567 & 0.151 & 0.08744 & 0.11765 & -0.0302802 & 0.030208022 \\
\hline 72 & 5 & 9 & -1.0946 & 0.151 & 0.13684 & 0.26471 & -0.12786132 & 0.127886132 \\
\hline 75 & 4 & 13 & -0.7015 & 0.151 & 0.2415 & 0.38235 & -0.14084903 & $\mathbf{0 . 1 4 0 8 4 9 0 3 1}$ \\
\hline 78 & 3 & 16 & -0.3083 & 0.151 & 0.37891 & 0.47059 & -0.09167635 & 0.091676351 \\
\hline 80 & 4 & 20 & -0.0463 & 0.151 & 0.48156 & 0.58824 & -0.10668019 & 0.1066801887 \\
\hline 85 & 4 & 24 & 0.60897 & 0.151 & 0.72873 & 0.70588 & 0.02284587 & 0.022845865 \\
\hline 88 & 4 & 28 & 1.0021 & 0.151 & 0.84185 & 0.82353 & 0.01832401 & 0.01834006 \\
\hline 90 & 4 & 32 & 1.26419 & 0.151 & 0.89692 & 0.94118 & -0.0442568 & 0.044256804 \\
\hline 93 & 2 & 34 & 1.65733 & 0.151 & 0.95127 & 1 & -0.04872674 & 0.048726737 \\
\hline
\end{tabular}

Based on the above table, the price of Lhitung $=0.140849031$ is obtained while from the list of liliefors at a significant level $\alpha=0.05$ and $n=34$ are:

$\frac{0,886}{\sqrt{n}}=\frac{0,886}{\sqrt{34}}=\frac{0,886}{5,830}=0,151$

Thus, the price of Lhitung $(0.140849031)<$ Ltable $(0.151)$ is obtained, which means that the data value of the learning group using the Three Stage Fishbowl Decision method comes from a normally distributed population. The normality test of group data of the Three Stage Fishbowl Decision method above is as follows: 
Known :

$\bar{x}=80,3529 S=7,631 n=34$

a. Determine standard numbers with the formula:

$z_{i}=\frac{x_{1}-\bar{x}}{s}=\frac{80-80,3529}{7,631}=-1,35669$

b. To determine $\mathrm{F}(\mathrm{Zi})$, the area value below the standard normal curve is used. How to determine $\mathrm{F}(\mathrm{Zi})$ is $\mathrm{Z}(0.05)$ use the $\mathrm{Z}$ table.

c. Determine the value of $\mathrm{S}(\mathrm{Zi})$ with the formula:

$$
\mathrm{S}\left(\mathrm{Z}_{1}\right)=\frac{\text { f komulatif }}{n}=\frac{4}{34}=0,11765
$$

This is to find the next $\mathrm{S}(\mathrm{Zi})$ data.

Determine Lhitung with the formula:

$\mathrm{L}=\left|\mathrm{F}\left(\mathrm{Z} \_\mathrm{i}\right)-\mathrm{S}\left(\mathrm{z} \_\mathrm{i}\right)\right|$

$\mathrm{L}=|0.08744-0,11765|$

$\mathrm{L}=|-0,03020802|$

$\mathrm{L}=0.03020802$

b. Homogeneity test

Table 4.7

Descriptive Data Post-test for each Variable

\begin{tabular}{|l|l|l|c|l|l|}
\hline $\begin{array}{l}\text { Class } \\
\text { sample }\end{array}$ & $\mathrm{N}$ & $\mathrm{dk}=(\mathrm{n}-1)$ & $\bar{x}$ & $s_{i}^{2}$ & $\mathrm{~S}$ \\
\hline Experiment & 34 & 33 & $\mathbf{9 0 , 2 3}$ & 42,06 & $\mathbf{6 , 4 8}$ \\
\hline Control & 34 & 33 & $\mathbf{8 0 , 3 5}$ & $\mathbf{5 8 , 2 3}$ & $\mathbf{7 , 6 3}$ \\
\hline
\end{tabular}

From table 4.7 it can be seen that the largest variance $=58.23$ and the smallest variance $=42.06$. So:

$\mathrm{F}=\frac{\text { varians terbesar }}{\text { varians terkecil }}$

$\mathrm{F}=\frac{58,23}{42,06}$

$\mathrm{F}=1,38$

From the table above, it can be seen that the class tested for variance similarity using the F test. From the calculation results above, the nutrient Fcount $=1.38$ was obtained. While for F0.05 $(33.33)=1.76$ because $\mathrm{F}<\mathrm{F} 0.05(33.33)$ or $(1.38<1.76, \mathrm{H} 0$ is accepted at a significant level $\alpha=$ 0.05 this means that both classes have same or homogeneous variance.

c. hypothesis testing 


\section{Data Hypothesis Testing}

Based on the results of the presayrat test shows that the data is normally distributed and homogeneous, then the data is then analyzed for hypothesis testing. Hypothesis test calculations are performed to determine whether or not there is an influence in learning, using the Three Stage Fishbowl Decision learning method on the ability to understand mathematics. Then the results of students' ability research will be analyzed by using statistical methods that compare the results of the post-test control class and the experimental class as follows:

Post-test was conducted to determine the final results of student grades after being treated both in the experimental class and the control class.

The price of table at $\mathrm{dk}=\mathrm{n} 1+\mathrm{n} 2=34+34-2=66$ at level $\alpha=0.05$ is table $=1.99656$ so $\mathrm{t}$ arithmetic (5.34) > table (1.99656). This means that $\mathrm{H} \alpha$ is accepted and $\mathrm{H} 0$ is rejected. This means that there is an influence between the Three stage fishbowl Decision learning method on the ability to learn mathematics in class XI TKR SMK Muhammadiyah 9 Medan T.P 2016/2017.

The magnitude of the influence of Three Stage Fishbowl Decision learning methods on the ability to learn mathematics cubes and blocks in class XI students of SMK Muhammadiyah 9 Medan T.P $2016 / 2017$ is $2.89 \%$.

\section{DISCUSSION OF RESEARCH RESULTS}

Based on the results of the research data shows that the initial ability research of the experimental class and the conversational class students, this can be seen from the results of the average pretest and post-test of the two classes. That the students' mathematics learning ability of the experimental class before learning is better than the control class with the average pretest of the experimental class 62.17 while the control class is 61.91 .

After learning the mathematics learning ability of the experimental class students is very better than the control class that is the experimental class with an average post-test 90.23 while the control class is 80.35 and the difference is better compared to before learning which is 9.88 Then based on the results of research conducted by researchers in class XI TKR 2 SMK Muhammadiyah 9 terrain it can be concluded that the average mathematics learning ability of students on cube and beam material using the Three Stage Fishbowl Decision learning method is better than the mathematics learning ability of control class students using lecture method. This is a significant increase in students' mathematical understanding abilities from the use of the Three Stage Fishbowl Decision learning method for students of SMK Muhammadiyah 9 Medan.

Then testing the hypothesis for students' mathematical understanding ability using the $t$ test. After raining data the mathematical understanding ability was found to be tcount> ttable, thitung (5.34)> ttable (1.99656). Then $\mathrm{H \alpha}$ is accepted and $\mathrm{H} 0$ is rejected. So it can be concluded from the hypothesis test that students' mathematics learning ability in the experimental class is better than the control class. This means that there is an influence between the Three Stage Fishbowl Decision learning method on the ability to learn mathematics in students of SMK Muhammadiyah 9 Medan T.P 2016/2017.

The magnitude of the influence of Three Stage Fishbowl Decision learning methods on the ability to learn mathematics cubes and blocks in class XI students of SMK Muhammadiyah 9 Medan T.P $2016 / 2017$ is $2.89 \%$.

By utilizing all media and learning resources, students will more easily understand the teaching material being delivered and be able to get involved in learning so that learning is meaningful. In addition, to obtain an increase in optimal learning abilities teachers need to apply a diverse and 
integrated learning method so that it will be able to improve students' mathematical understanding abilities.

Thus the learning of mathematics in cube and block discussion using the Three Stage Fishbowl Decision learning method can be used as an appropriate alternative in learning that can affect the ability to learn mathematics in students of SMK Muhammadiyah 9 Medan TP 2016/2017, because with this method the ability to understand students increase.

\section{CONCLUSION}

The conclusions that researchers took as suggestions to related parties in the mathematics teaching and learning process include the following:

1. The application of the Three stage fishbowl decision learning method is expected to be a choice to improve students' mathematics learning abilities.

2. The results of the research can be used as a guideline in taking steps that use the application of the Three-Stage Fishbowl decision learning method

3. The results of the study should be used as a guideline for further similar researchers and can perfect the research because there are still deficiencies in the application of data, data processing techniques and data analysis techniques.

\section{REFERENCES}

Arikunto, Suharsimi. 2010. Dasar-Dasar Evaluasi Pendidikan. Jakarta: Bina Aksara. , 2006. Prosedur Penelitian Pendekatan Praktek. Jakarta : Rineka Cipta , 2009. Pengolahan Data Statistik dengan SPSS 16.0. Jakarta : Salemba Infotek

Hamalik, Oemar. 2003. Proses Belajar Mengajar. Jakarta: Penerbit Bumi Aksara

Marzano, R.J., Brandt, R.S., Hughes, C.S., Jones, B.F., Presseissen, B.Z., Rankin, S.C., Suhor, C. (1988).Dimensins of thinking: A framework for curriculum and Instruction. Alexandria, V.A: Association forSupervision and Curriculum Development.

Noormandiri, B.K. 2007. Matematika untuk SMK Kelas XI. Jakarta : Erlangga\

Purwanto, 2011. Active Learning : 101 Strategi Pembelajaran Aktif. Yogyakarta : Pustaka Insan Madani.

Press.Badan Standar Nasional Pendidikan. (2006). Panduan Kurikulum Tingkat Pendidikan SD/MI. Jakarta: Kencana Bhakti.

Sudjana, Nana 2005. Penilaian Hasil Proses Belajar Mengajar. Bandung:

Remaja Rosdakarya

Slameto, 2010. Belajar dan Faktor-faktor yang mempengaruhinya. Jakarta : Rineka Cipta.

Sugiyono. 2009. Metode Penelitian Pendidikan. Bandung: Alfabeta

Sugiyono, 2011. Statistika Untuk Penetian. Bandung : Alfabeta

Suharta. 2005. Matematika Realistik Apa dan Bagaimana.( Online). http://www.depdiknas.go.id (di akses pada tanggal 15 September 2007). 
Sumantri, M. Syarif. (2015). Strategi Pembelajaran :Teori Dan Praktik Di Tingkat Pendidikan Dasar. Jakarta :PT.Raja grafindo Persada.

Riduwan. 2004. Metode dan Teknik Menyusun Tesis. Bandung. Alfabeta.

Winkel, W.S. 2007. Psikologi Pendidikan dan Evaluasi Belajar. Jakarta: Gramedia. 